\title{
Rancang Bangun Inverter Menggunakan IC CD4047 INPUT Batrai 12 VDC Ke Output Lampu 220 VAC Frekuensi 50-60 HZ
}

\author{
Andre Saputra $^{1^{*}}$, Fadli Eka Yandra ${ }^{2}$ \\ ${ }^{1,2}$ Teknik Listrik, Fakultas Teknik, Universitas Batanghari \\ *Correspondence Email: anddree19@gmail.com; fadli.eka.yandra@unbari.ac.id
}

\begin{abstract}
Abstrak. Inverter merupakan salah satu alat elektronika yang berfungsi untuk mengubah arus searah (DC) menjadi arus bolakbalik (AC) dengan besaran tegangan dan frekuensi dapat diatur, output suatu inverter berupa tegangan AC dengan bentuk berupa gelombang kotak (Square Wave).kemudian dilakukan pengujian dengan beda jenis Trafo Step Up CT untuk mendapatkan hasil pengujian dan analisa. Dan prinsip kerja dari rangkain inverter ini yaitu, pulsa driver Transistor TIP122 dan 2 N3055 dibangkitkan oleh pembangkit pulsa IC CD4047, pulsa dari rangkaian Multivibrator Astambil ini adalah 2 pulsa dengan fasa yang saling berkebalikan $180^{\circ}$. Pulsa Q dan Q tersebut digunakan untuk memberikan driver ke Transistor TIP122 dan 2 N3055 dan akan menginduksi Transformator Step Up secara bergantian. Sehingga Transformator Step Up akan dapat menginduksi secara 2 arah dari titik CT. karena proses induksi tersebut maka pada primer Transformator akan memberikan tegangan AC induksi sebesar 220 Volt dengan bentuk gelombang kotak (square wave). Inverter jenis ini hanya bisa untuk lampu saja, kelebihannya harganya lebih murah karena difungsikan untuk membackup lampu saja.
\end{abstract}

Kata Kunci: Rancang Bangun Inverter; Transistor 2N3055; Square Wave.

Abstract. Inverter is an electronic device that functions to change current direct (DC) into alternating current (AC) with the magnitude of the voltage and frequency can be adjusted, the output of an inverter in the form of AC voltage in the form of a square wave. Then testing with different types of Step Up CT transformers to get the test results and analysis. And the working principle of this inverter circuit is that the TIP122 and 2N3055 Transistor driver pulses are generated by the IC CD4047 pulse generator, the pulses of the Astambil Multivibrator circuit are 2 pulses with a phase that reverses $180^{\circ}$. The $Q$ and $Q$ pulses are used to provide drivers to the TIP122 and 2 N3055 transistors and will induce the Step Up Transformer in turn. So the Step Up Transformer will be able to induce in 2 directions from the CT point. because of the induction process, the transformer primary will provide an AC voltage of 220 volts with a square wave shape. This type of inverter can only be used for lamps, the price is cheaper because it is used to back up the lamp.

Keywords: Inverter Build Design; Transistor 2N3055; Square Wave.

\section{PENDAHULUAN}

Beberapa tahun belakangan ini perkembangan di dunia elektronika mengalami kemajuan pesat, semua itu di dasari oleh kemajuan pendidikan yang ada selama ini. Seiring dengan keadaan yang semakin maju terutama dalam dunia Elektronika, pasti membutuhkan sumber arus untuk menjalankan alat-alat elektronika tersebut.

Inverter adalah perangkat elektrik yang digunakan untuk mengubah arus searah (DC) menjadi arus bolakbalik (AC). Inverter mengkonversi DC dari perangkat seperti baterai, panel surya / solar cell menjadi AC. Dalam hal ini sumber arus dari PLN saja terkadang tidak memadai, terutama pada desa-desa tertinggal yang tidak dapat menggunakan sumber arus dari PLN. Oleh karena itu, hal ini dapat di atasi dengan membuat suatu alat yang yang dapat mengantikan sumber arus dari PLN tersebut. Maka dengan itu penulis membuat suatu rangkaian elektronika yang menghasilkan tegangan $\mathrm{AC}$ yang dinamakan "Rangkaian Inverter DC ke AC".

Inverter ini sangat berfungsi sebagai penyedia listrik cadangan baik di kendaraan maupun dirumah, sebagai emergency power saat aliran listrik rumah padam.

\section{Inverter}

Inverter adalah sebuah alat yang merubah listrik tegangan DC menjadi listrik tegangan AC dengan nilai frekuensi yang dapat dirubah. Inverter menerima sumber tegangan DC sebagai tegangan masukan yang dapat diperoleh dari akumulator (aki). Dengan peroses penyaklaran dari komponen yang ada pada rangkaian inverter.

Kualitas inverter merupakan penentu dari kualitas daya yang dihasulkan oleh suatu sistem. Inverter berfungsi merubah tegangan DC batrai atau rangkaian rectifier-charger menjadi tegangan $\mathrm{AC}$, sinyal atau gelombang keluaran berbentuk kotak setelah melalui pembentukan gelombang dan rangkaian filter. Tegangan keluaran yang dihasilkan harus stabil bail amplitude tegangan maupun frekuensinya [5].

\section{Prinsip Kerja Inverter}

Pulsa driver Transistor TIP122 dan 2N3055 dibangkitkan oleh pembangkit pulsa IC CD4047, pulsa dari rangkaian multivibrator astambil ini adalah 2 pulsa dengan fasa yang saling berkebalikan $180^{\circ}$. Pulsa Q dan $\mathrm{Q}$ tersebut digunakan untuk memberikan driver ke Transistor TIP122 dan 2N3055 dan akan menginduksi 
Transformator Step Up secara bergantian. Sehingga Transformator Step Up akan mendapat induksi secara 2 arah dari titik CT. Karena proses induksi tersebut maka pada primer Transformator akan memberikan tegangan AC induksi dengan bentuk gelombang kotak ( Square Wave ).

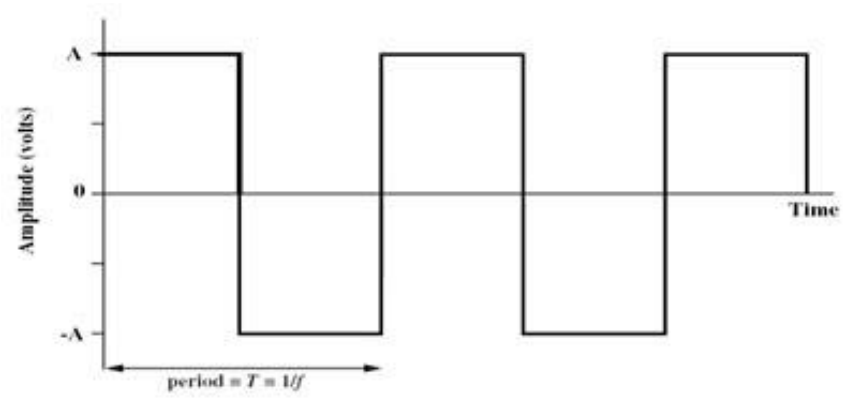

Gambar 1. Sinyal IC CD4047

\section{METODE}

Diagram Alur

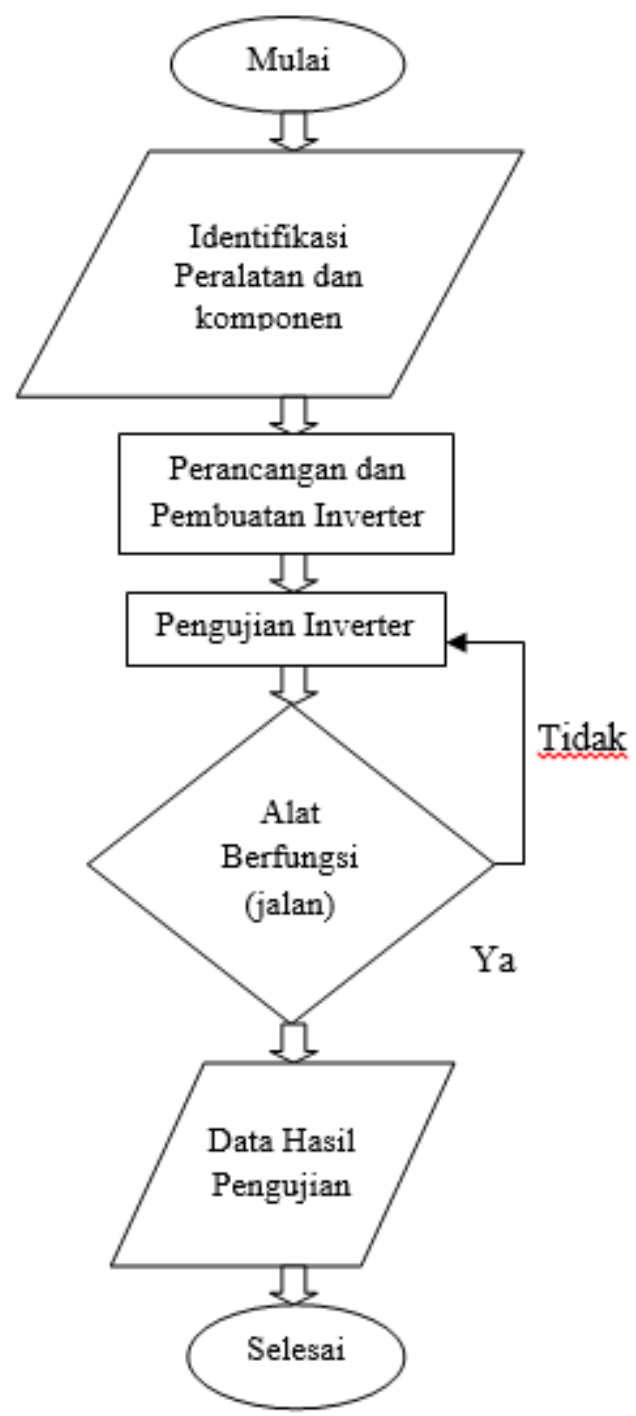

Gambar 2. Diagram Alur Optimasi Inverter

\section{Blok Diagram}

Secara umum pembuatan inverter dengan IC CD4047 ini dapat dipresentasikan dengan blok diagram yang ditunjukan pada Gambar 3. Berikut :

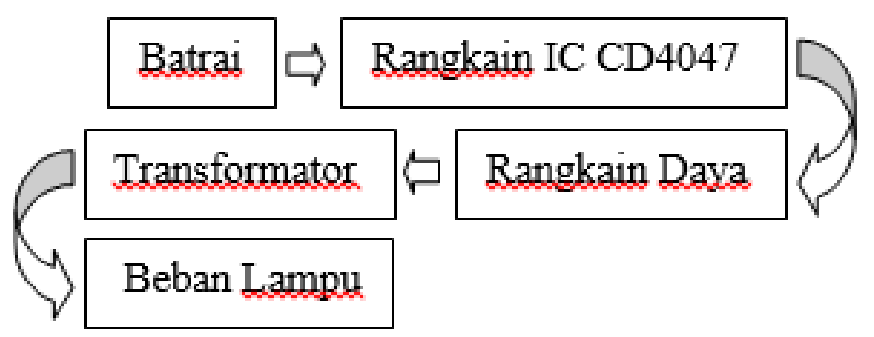

Gambar 3. Rancangan Inverter

\section{Pengujian Inverter}

Menghasilkan sebuah perangkat inverter dengan masukkan tegangan $12 \mathrm{~V}$ DC berubah keluarannya menjadi tegangan $220 \mathrm{~V}$ AC dengan frekuensi $50-60 \mathrm{~Hz}$.

\section{Data Hasil Pengujian}

Tujuan yang didapat adalah data dari hasil pengukuran dari masukknya arus dan tegangan dari Baterai, Keluaran arus dan tegangan dari Trafo Step Up $\mathrm{Ct}$, Berapa $\mathrm{Hz}$ Frekuensi yang dihasilkan inverter, melakukan ujicoba dengan beda jenis Trafo CT, dan menguji gelombang keluaran dari inverter menggunakan Osiloskop.

\section{HASIL DAN PEMBAHASAN}

Pengujian Inverter Dengan IC CD4047 Diset Sebagai Rangkaian Astable Multivibrator Sehingga Pada Kaki IC Nomor 10 dan 11 Memiliki Output Square Wave Yang Komplemen ( Saling Berlawanan Outputnya ). Output Ini Yang Diset Agar memiliki Frekuensi $50 \mathrm{~Hz}$ Pada Masing-masing Output.

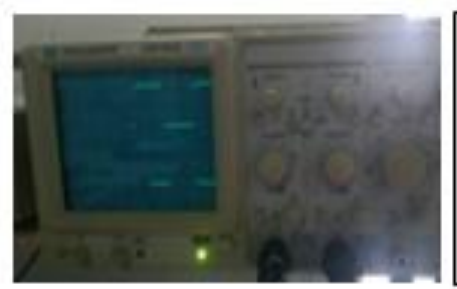

Keterangan : Probe 1 ( $x 1$ ) Probe 2 (x1) Volt/div : $5 \mathrm{~V}$

Time/div : $5 \mathrm{~ms}$

Frekuensi : $50 \mathrm{~Hz}$

Gambar 4. Gelombang Kaki 10 dan 11 IC CD4047

\section{Rangkaian Penghasil Pulsa}

Rangkaian penghasil pulsa berfungsi untuk menghasilkan pulsa pemicu Transistor daya, pulsa dihasilkan oleh IC CD4047. 


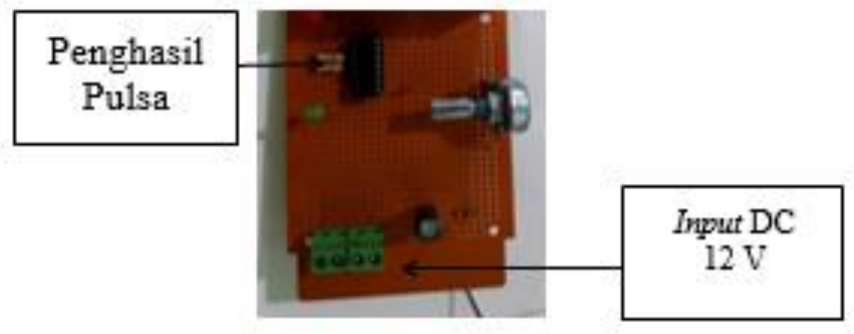

Gambar 5. Rangkaian Penghasil Pulsa

\section{Rangkaian Daya}

Rangkaian daya pada pembuatan inverter ini terdiri dari Resistor 4,7k, Transistor TIP122, Transistor TIP2N3055, Resistor 0,1 Ohm, dan Dioda BY127.

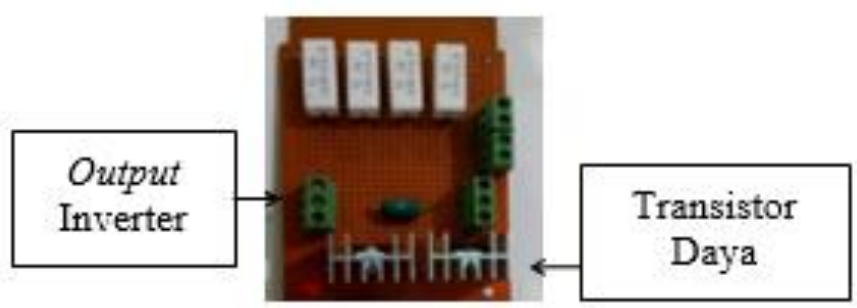

Gambar 6. Rangkaian Daya

\section{Rangkaian Inverter Keseluruhan}

Rangkaian inverter ini dilengkapi dengan IC CD4047 yang berfungsi untuk menghasilkan sebuah pulsa pemicu Transistor daya, selanjutnya dilewatkan kerangkaian Transistor driver dan output dari driver ini yang akan memicu Transistor daya.

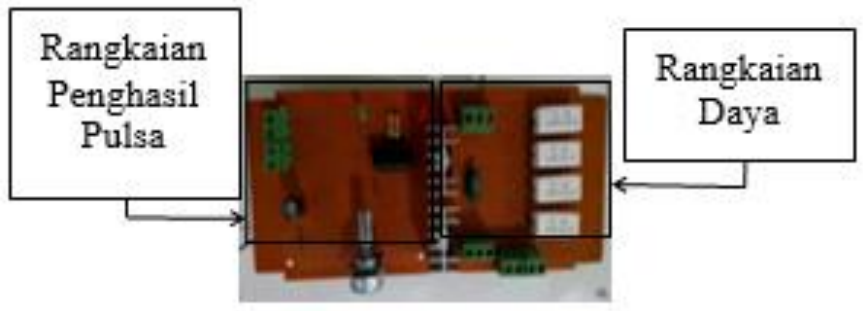

Gambar 7. Rangkaian Skematik Inverter

\section{Cara pengoprasian}

1. Hubungkan batrai DC 12 Volt pada Input inverter DC 12 Volt.

2. Hubungkan beban lampu pada stopkontak Output pada inverter.

\section{Hasil Pengujian Trafo $2 A$}

Pada hasil yang didapat setelah inverter dibuat pada $\mathrm{PCB}$, didapatkan bahwa saat inverter tersebut diberikan input 12 Volt DC, akan menghasilkan output sebesar 24 Volt AC, kemudian output tersebut disambungkan pada Transformator, dan ternyata pada saat tegangan dari output Transformator tersebut diukur didapatkan tegangan 145 Volt.

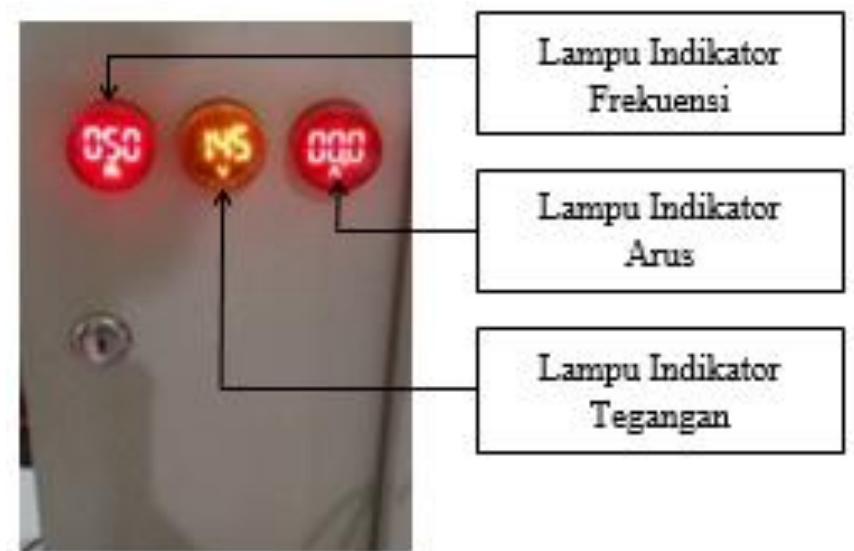

Gambar 8. Lampu Indikator Daya Utama Inverter 145 VAC

Tabel 1. Hasil Pengukuran Menggunakan Transformator 2 Ampere

\begin{tabular}{cccc}
\hline $\begin{array}{c}\text { Input Arus } \\
\text { 12 VDC }\end{array}$ & $\begin{array}{c}\text { Lampu LED } \\
(\mathrm{W})\end{array}$ & $\begin{array}{c}\text { Frekunsi } \\
(\mathrm{Hz})\end{array}$ & $\begin{array}{c}\text { Output Arus } \\
145 \mathrm{VAC}\end{array}$ \\
\hline $0,4 \mathrm{~A}$ & 5 & 50 & $0,03 \mathrm{~A}$ \\
$0,5 \mathrm{~A}$ & 7 & 50 & $0,04 \mathrm{~A}$ \\
$0,8 \mathrm{~A}$ & 10 & 50 & $0,06 \mathrm{~A}$ \\
$1,1 \mathrm{~A}$ & 14 & 50 & $0,09 \mathrm{~A}$ \\
\hline
\end{tabular}

Tabel 1 merupakan hasil dari masing-masing beban yang diberikan, beban yang diberikan berkisar dari 5 Watt sampai 14 Watt 145 Volt, dengan beban yang diberikan berupa lampu LED.

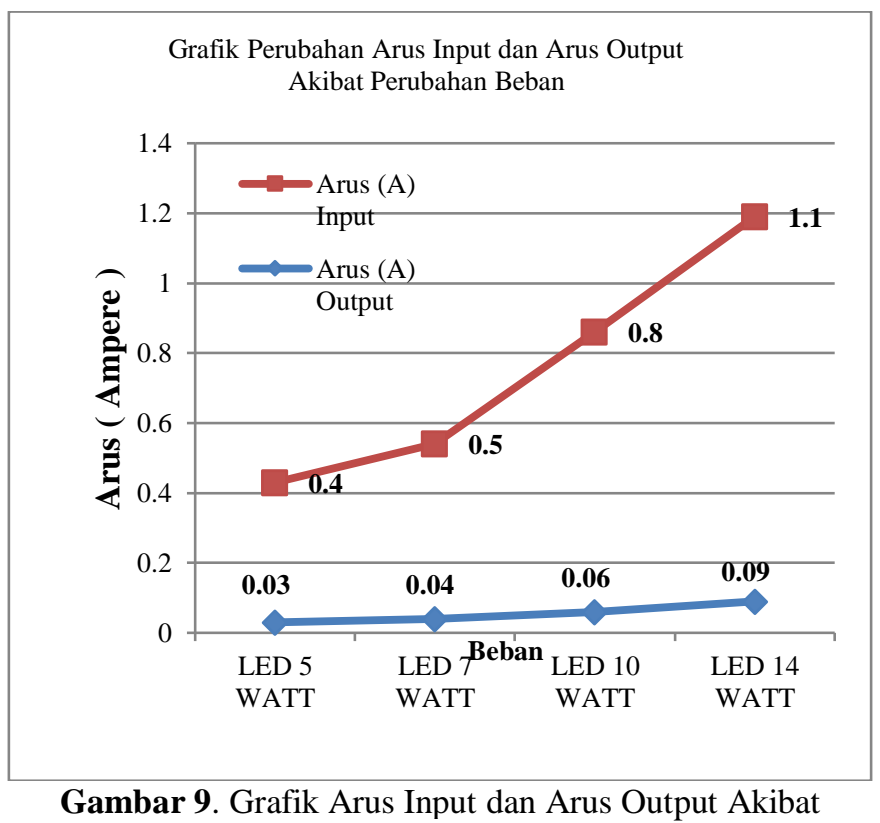
Perubahan Beban.

Grafik pada gambar 9 menunjukkan perubahan arus input dan arus output akibat perubahan beban, semakin besar beban yang diberikan maka arus inputnya semakin besar pula, begitu pula untuk beban output semakin besar beban yang digunakan maka arus outputnya akan semakin besar pula. 


\section{Hasil Pengujian Trafo 5A}

Pada hasil yang didapat setelah inverter dibuat pada PCB, didapatkan bahwa saat inverter tersebut diberikan input 12 Volt DC, akan menghasilkan output sebesar 24 Volt AC, kemudian output tersebut disambungkan pada Transformator, dan ternyata pada saat tegangan dari output Transformator tersebut diukur didapatkan tegangan 171 Volt

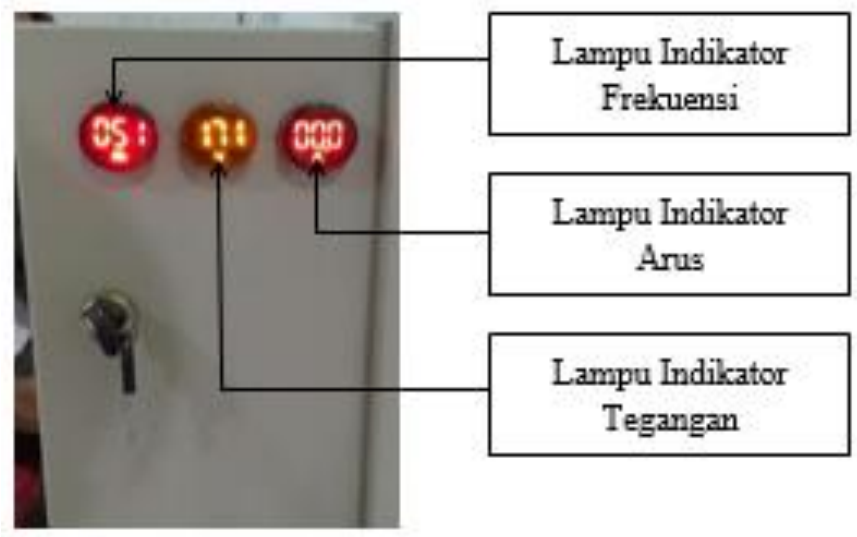

Gambar 10. Lampu Indikator Daya Utama Inverter 171 VAC

Tabel 2. Hasil Pengukuran Menggunakan Transformator 5 Ampere

\begin{tabular}{cccc}
\hline $\begin{array}{c}\text { Input Arus } \\
\text { 12 VDC }\end{array}$ & $\begin{array}{c}\text { Lampu LED } \\
(\mathrm{W})\end{array}$ & $\begin{array}{c}\text { Frekunsi } \\
(\mathrm{Hz})\end{array}$ & $\begin{array}{c}\text { Output Arus } \\
171 \mathrm{VAC}\end{array}$ \\
\hline 0,4 A & 5 & 51 & $0,02 \mathrm{~A}$ \\
$0,5 \mathrm{~A}$ & 7 & 51 & $0,04 \mathrm{~A}$ \\
$0,8 \mathrm{~A}$ & 10 & 51 & $0,05 \mathrm{~A}$ \\
$1,1 \mathrm{~A}$ & 14 & 51 & $0,08 \mathrm{~A}$ \\
\hline
\end{tabular}

Tabel 2 merupakan hasil dari masing-masing beban yang diberikan, beban yang diberikan berkisar dari 5 Watt sampai 14 Watt 171 Volt, dengan beban yang diberikan berupa lampu LED.

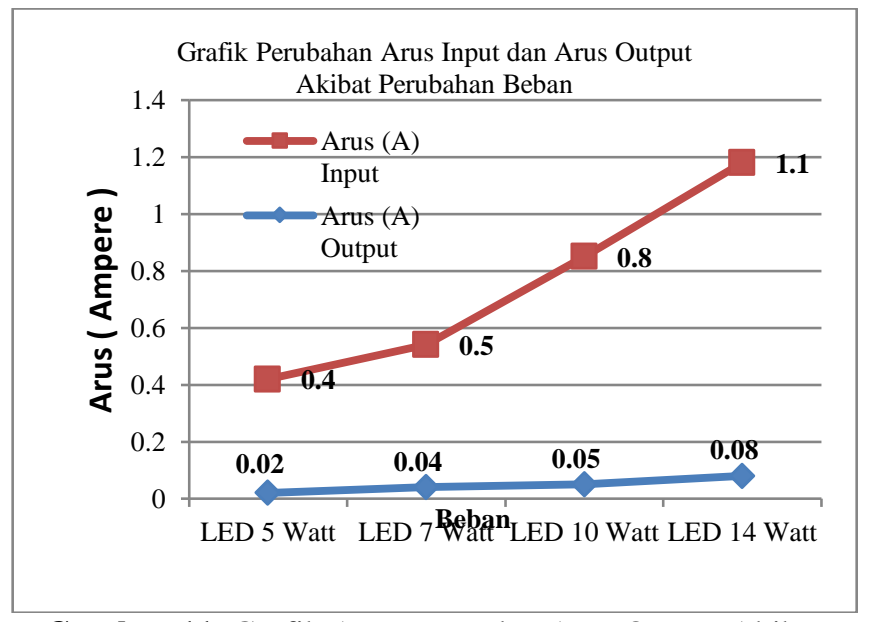

Gambar 11. Grafik Arus Input dan Arus Output Akibat Perubahan Beban.

Grafik pada gambar 11 menunjukkan perubahan arus input dan arus output akibat perubahan beban, semakin besar beban yang diberikan maka arus inputnya semakin besar pula, begitu pula untuk beban output semakin besar beban yang digunakan maka arus outputnya akan semakin besar pula.

\section{Hasil Pengujian Trafo 10A}

Pada hasil yang didapat setelah inverter dibuat pada PCB, didapatkan bahwa saat inverter tersebut diberikan input 12 Volt DC, akan menghasilkan output sebesar 24 Volt AC, kemudian output tersebut disambungkan pada Transformator, dan ternyata pada saat tegangan dari output Transformator tersebut diukur didapatkan tegangan $125 \mathrm{Vol}$

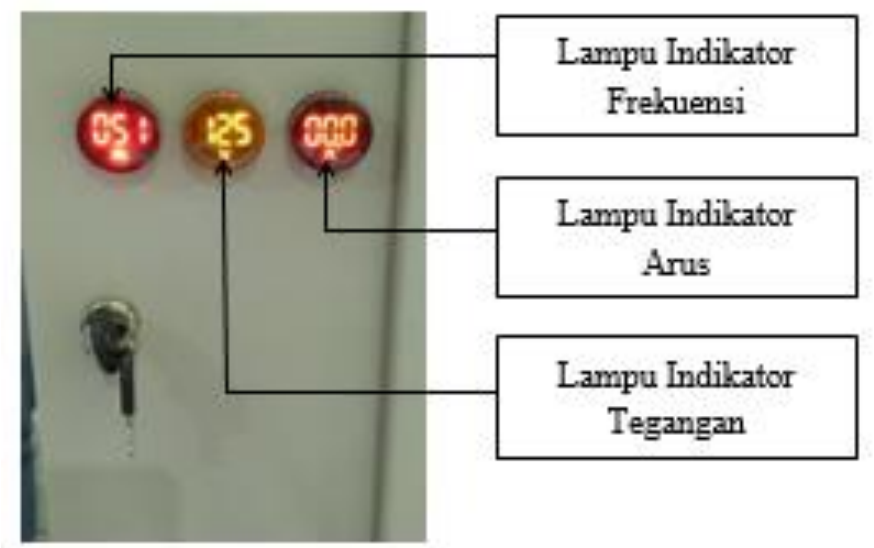

Gambar 12. Lampu Indikator Daya Utama Inverter 125 VAC

Tabel 3. Hasil Pengukuran Menggunakan Transformator 5 Ampere

\begin{tabular}{cccc}
\hline $\begin{array}{c}\text { Input Arus } \\
\text { 12 VDC }\end{array}$ & $\begin{array}{c}\text { Lampu LED } \\
(\mathrm{W})\end{array}$ & $\begin{array}{c}\text { Frekunsi } \\
(\mathrm{Hz})\end{array}$ & $\begin{array}{c}\text { Output Arus } \\
125 \mathrm{VAC}\end{array}$ \\
\hline $0,4 \mathrm{~A}$ & 5 & 51 & $0,04 \mathrm{~A}$ \\
$0,5 \mathrm{~A}$ & 7 & 51 & $0,05 \mathrm{~A}$ \\
$0,8 \mathrm{~A}$ & 10 & 51 & $0,08 \mathrm{~A}$ \\
$1,1 \mathrm{~A}$ & 14 & 51 & $0,1 \mathrm{~A}$ \\
\hline
\end{tabular}

Tabel 3 merupakan hasil dari masing-masing beban yang diberikan, beban yang diberikan berkisar dari 5 Watt sampai 14 Watt 125 Volt, dengan beban yang diberikan berupa lampu LED.

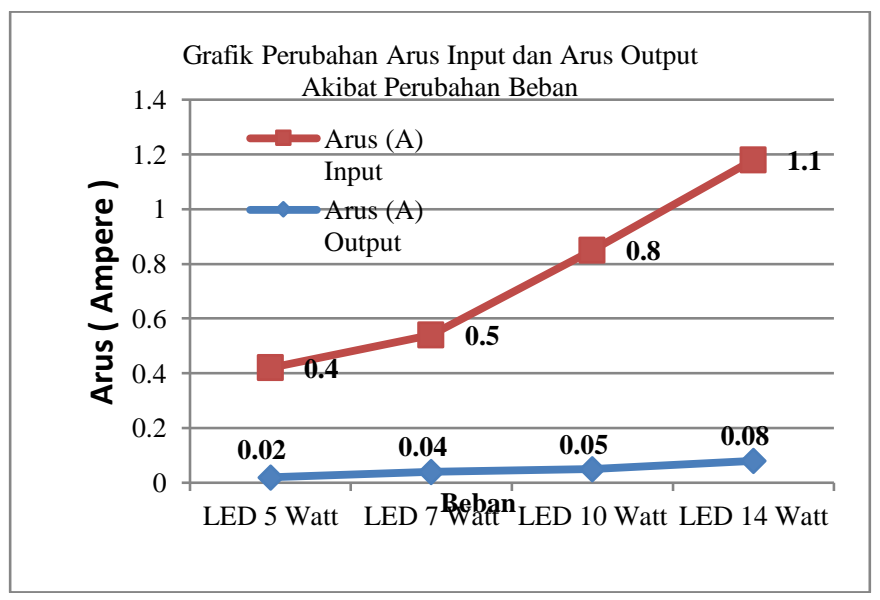

Gambar 13. Grafik Output Inverter 125 VAC 
Grafik pada gambar 13 menunjukkan perubahan arus input dan arus output akibat perubahan beban, semakin besar beban yang diberikan maka arus inputnya semakin besar pula, begitu pula untuk beban output semakin besar beban yang digunakan maka arus outputnya akan semakin besar pula.

\section{Pembahasan}

Rangkaian inverter DC ke AC diatas disusun dari beberapa bagian utama sebagai berikut :

1. Pembangkit pulsa, Rangkaian ini berfungsi untuk membangkitkan frekuensi kerja inverter, bagian ini dibangun dengan IC CD4047.

2. Driver inverter, bagian ini berfungsi mengontrol sistem induksi Tranformator step up, komponen yang digunakan adalah 2 unit Transistor TIP122 dan 4 unit Transistor 2N33055.

3. Penaik tegangan ( Step Up ), bagian ini berfungsi untuk menaikan tegangan 12 Volt menjadi 220 Volt $\mathrm{AC}$, bagian ini menggunakan perbandingan hasil pengujian dengan 3 (Tiga) jenis Tranformator 2A, 5A, 10A.

\section{SIMPULAN}

Dari penelitian yang dilakukan dapat ditarik kesimpulan sebagai berikut :

1. Didalam bagian ini dibahas tentang rangkaian Inverter DC ke AC yang artinya rangkaian yang akan mengubah 12 Volt DC ke 220 Volt AC sebagai output maksimal yang dihasilkan. Rangkaian ini cukup sederhana karena Cuma menggunakan 1 buah IC CD4047, 2 buah Transistor yaitu jenis TIP122 NPN, 4 buah Transistor jenis 2N3055 Jengkol NPN.

2. Komponen yang paling berperan penting adalah Transistor jenis 2N3055 NPN, kaki emitter pada keempat Transistor terhubung ke ground, kaki collector terhubung ke input 12 VAC dan 12 VAC Transformator sehingga $12 \mathrm{VAC}$ dan $12 \mathrm{VAC}$ akan saling bergantian tertutup dan terbuka.

3. Pada saat dilakukan penelitian ini bentuk gelombang yang dihasilkan inverter berupa gelombang Square Wave.

\section{DAFTAR PUSTAKA}

[1] Albert Paul Malvino, 2003, Prinsip - Prinsip Elektronika, Jakarta: Salemba Teknika.

[2] Fauzi, Ahmad, 2007, Aplikasi inverter untuk mengurangi konsumsi daya pada beban puncak, Tugas Akhir Elektro Industri - EEPIS.

[3] Samson, DMS, 2005, Perancangan dan pembuatan inverter, Sekolah Tinggi Teknologi Pekanbaru, Indonesia.

[4] Sutrisno. 1986. Elektronika dan Teori Penerapannya. Edisi Pertama. Bandung: ITB.

[5] Depari, Ganti. 1988. Pokok pokok Elektronika. Bandung: M2S Bandung. 